\title{
Confirmation of the presence of Dasyprocta azarae in the Paraguayan Chaco
}

\section{Confirmación de la presencia de Dasyprocta azarae en el Chaco paraguayo}

\author{
Daniela Tabilo ${ }^{1 *}$, Andrea Weiler ${ }^{1}$, Alberto Esquivel ${ }^{2}$, Karim Musálem² ${ }^{2}$ Belén Zaldivar ${ }^{1}$, Estefanía Valiente ${ }^{1}$, Karen Chavez ${ }^{1}$, \\ Patricia Salinas ${ }^{1}$, and Yolanda Ramos ${ }^{1}$
}

\begin{abstract}
'Universidad Nacional de Asunción, Facultad de Ciencias Exactas y Naturales (FACEN), Departamento de Biología, Colección Zoológica de FACEN (CZCEN). Campus Universitario, 1039, San Lorenzo, Departamento Central, Paraguay. Email: danitabilo97@ gmail.com (DT), andreaweiler1@gmail.com (AW), planetzv@gmail.com (BZ), tefvaliente@gmail.com (EV), karenyaninna.18@ gmail.com (KCh), patrisali93@gmail.com (PS), yoliramos0@gmail.com (YR).

${ }^{2}$ World Wildlife Fund Paraguay. Avenida Bernardino Caballero 191, 1575, Asunción. Departamento Central, Paraguay. Email: aesquivel@wwf.org.py (AE), kmusalem@wwf.org.py (KM).

*Corresponding author
\end{abstract}

\begin{abstract}
Azara's Agouti (Dasyprocta azarae) was included within the mastofauna of Paraguay's Chaco until 2016. Later literature exclude it from the region, since no published records include a concrete evidence like museum specimens, DNA sequences or photos. The objective of this note is to provide evidence of the distribution of $D$. azarae in the Paraguayan Chaco to help understand its distribution in Paraguay. The distribution of $D$. azarae was re-evaluated by a review of literature, museum specimens, and photograph analysis from the Zoological Collection of the Faculty of Exact and Natural Sciences (ZCENS) to update the species' geographic range. The photographs were captured via camera trapping methods. We provide new records of Azara's Agouti at three locations, two of them located in the transition zone between the Dry Chaco and Pantanal ecoregions, and one in the Dry Chaco ecoregion of the Paraguayan Chaco. Recent literature also confirms the presence of the species in the Humid Chaco ecoregion. Along with other recently published records, we confirm the presence of the species in three ecoregions of the Paraguayan Chaco. With these documented records, its distribution is expanded to more than $270 \mathrm{~km}$ west into the region.
\end{abstract}

Key words: Azara's Agouti; camera trapping; distribution; geographic range; monitoring fauna.

Dasyprocta azarae fue considerada dentro de la mastofauna de la región occidental del Paraguay hasta el año 2016. Literatura posterior excluye a la especie de la región ya que no existe ningún registro publicado que incluya evidencia concreta como ejemplares de museo, secuencias de ADN, o fotografías. El objetivo de esta nota es demostrar evidencia de la distribución de D. azarae en el Chaco Paraguayo para aportar al conocimiento de su distribución en Paraguay. La distribución actual de la especie fue re-evaluada mediante una revisión de literatura, ejemplares de museo, y fotografías de la fototeca de la Colección Zoológica de la Facultad de Ciencias Exactas y Naturales (CZCEN) para actualizar la misma. Las fotografías provienen de métodos de foto trampeo. Demostramos registros de Agouti de Azara en tres localidades, dos de ellos en la zona de transición entre las ecorregiones Chaco Seco y Pantanal y uno en el Chaco Seco del Chaco Paraguayo. Literatura reciente también confirma la presencia de la especie en el Chaco Húmedo. En conjunto con otros registros que fueron recientemente publicados, confirmamos la presencia de la especie en tres ecorregiones del Chaco Paraguayo. Con estos registros, su distribución se amplía más de $270 \mathrm{~km}$ al oeste dentro de la región.

Palabras clave: Agouti; distribución; fototrampeo; monitoreo de fauna; rango geográfico.

(C) 2020 Asociación Mexicana de Mastozoología, www.mastozoologiamexicana.org

Azara's Agouti, Dasyprocta azarae, is a member of the family Dasyproctidae which includes two genera and 13 species (Wilson and Reeder 2005). It is a frugivorous rodent that stores uneaten fruits and nuts by burying them in the ground. In doing so, it plays an important role as a seed disperser for fruit bearing trees (Redford and Eisenberg 1992). It is also preyed upon by carnivorous mammals such as Leopardus wiedii which is currently listed as Near Threatened by the IUCN (de Oliveira et al. 2015), making D. azarae an important prey species.

According to IUCN's Red List, it is present in southwestern and south-central Brazil, from Mato Grosso and Goias states to the coast in Rio Grande do Sul and Sao Paul States, in Bolivia south of the Rio Beni, eastern Paraguay and northeastern Argentina (Catzeflis et al. 2016). Myers et al. (2002) describes the distribution of the species extending to the Oriental and Occidental regions of Paraguay. Rumbo (2010) also places the species in the Occidental region, but this was based mostly on a previous list (Gamarra de Fox and Martin 1996) and not on concrete evidence. Most recently, Patton and Emmons (2015) and de La Sancha and Ortiz (2017) only place the species in the oriental region due to the lack of evidence supporting its presence in Paraguay's occidental region.

The species has been recently confirmed in Corrientes, Argentina (Chatellenaz et al. 2015), which is evidence that its distribution is still poorly known. This supports its categorization as a Data deficient species in IUCN's Red List (Catzeflis et al. 2016), even though it is considered a Least concern species at the national level (Asociación 
Paraguaya de Mastozoología and Secretaría del Ambiente 2017). The objective of this note is to provide evidence of the distribution of $D$. azarae in the Paraguayan Chaco to help understand its distribution in Paraguay.

The current distribution of $D$. azarae was re-evaluated and updated via a review of literature, museum specimens, and photographs from the Zoological Collection of the Faculty of Exact and Natural Sciences (ZCENS) at Universidad Nacional de Asunción that had not previously been considered. These photographs were obtained through camera trapping methods developed in a series of projects that monitor biodiversity at cattle ranches in all three departments of the Paraguayan Chaco. The projects began in 2017 and are still underway. In all projects, photographs were considered to be independent records if they were captured at least one hour apart. All photographs obtained were considered, but only those from camera traps at Estancia San Juan ( $21^{\circ} 08^{\prime} 13.27^{\prime \prime} \mathrm{S}, 60^{\circ} 27^{\prime} 47.91^{\prime \prime} \mathrm{W}$ ), Estancia Cerro Corá $\left(20^{\circ} 16^{\prime} 29.2^{\prime \prime} \mathrm{S}, 58^{\circ} 15^{\prime} 54.6^{\prime \prime} \mathrm{W}\right)$ and Estancia Santa Teresita $\left(20^{\circ} 24^{\prime} 12.5^{\prime \prime} \mathrm{S}, 58^{\circ} 26^{\prime} 09.4^{\prime \prime} \mathrm{W}\right)$ provided data on D. azarae. Camera traps were active for 720,124 , and 234 days respectively. The first ranch lies in the Dry Chaco ecoregion and the last two are located in the transition zone between the Pantanal and Dry Chaco ecoregions (Mereles et al. 2013). Museum specimens were searched for through literature and museums with $D$. azarae specimens collected in eastern Paraguay were contacted to request further information.

Through our studies, we have obtained a total of 38 independent photographs and one video of the species via camera traps between 2017 and 2019 at the three cattle ranches; San Juan (one record) in the Dry Chaco ecoregion, and Cerro Corá (27 records) and Santa Teresa (ten records) in the transition zone between the Dry Chaco and Pantanal ecoregions.

One existing museum specimen (FMNH 64200) was located in the zoological collection of the Field Museum of Natural History in Chicago. It was collected in Orloff $\left(22^{\circ}\right.$ $\left.18^{\prime} 59.4^{\prime \prime} \mathrm{S}, 59^{\circ} 54^{\prime} 17.64^{\prime \prime} \mathrm{W}\right)$, in the Boquerón Department in 1946 by J. Unger (Londoño-Gaviria et al. 2018). Although it was collected in Paraguay's occidental region, this specimen was not considered by de La Sancha and Ortiz (2017) or Patton and Emmons (2015), possibly due to its age.

Additionally, Gonzáles et al. (2019) provides new photographic records of the species captured via camera traps at Estación Los Tres Gigantes (20 4' 42.44" S, 58 9' 39.06" W), which is located in the Pantanal ecoregion. Finally, Caballero-Gini et al. (2020) provides records of the species at cattle ranch Estancia Playada ( $24^{\circ} 57^{\prime} 59.88^{\prime \prime}$ S, 57 $21^{\circ} 56.12^{\prime \prime}$ W), located in the Humid Chaco ecoregion.

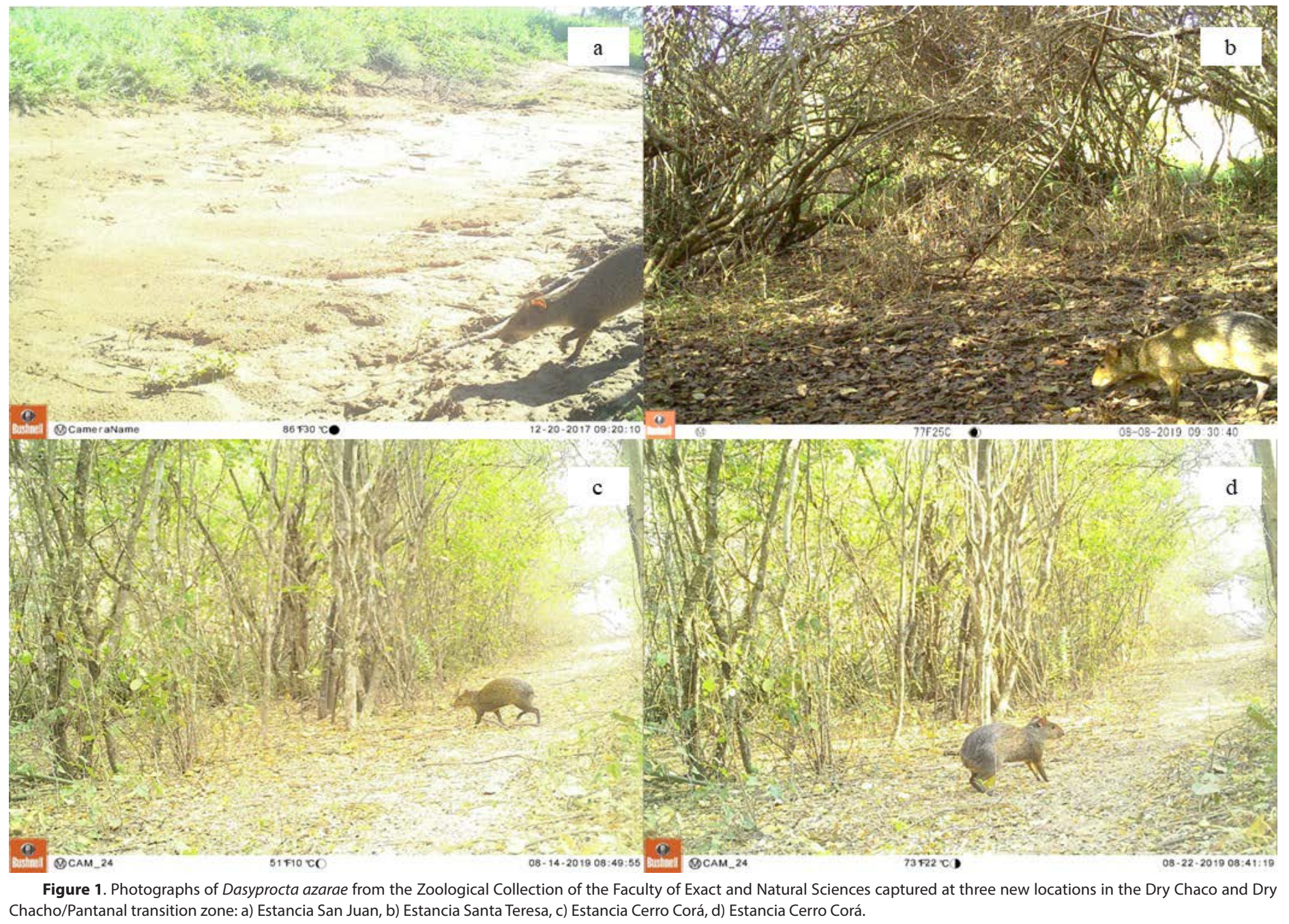




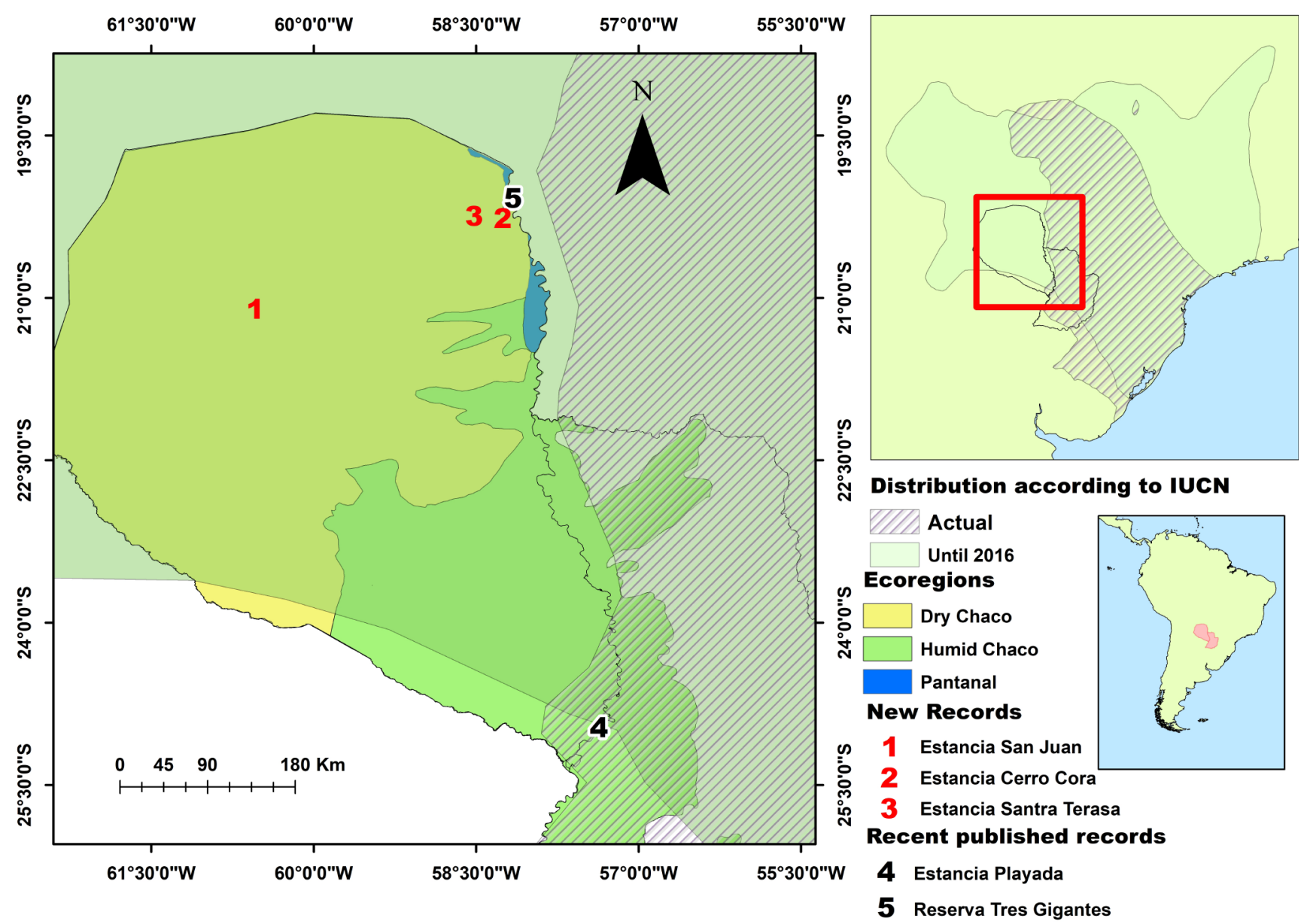

Figure 2. A comparison of the IUCN distribution maps of Dasyprocta azarae before and after 2016 along with newly considered records of the species in Paraguay's occidental region.

Together, these records confirm the presence of the species in all three ecoregions in the occidental region and serve as evidence that its distribution expands west of the Paraguay River as was thought until 2016 (Figure 2). Twenty-seven individuals were photographed at Estancia Cerro Corá and 10 were photographed at Estancia Santa Teresa. These locations are close to each other and are in the northeastern area of the Dry Chaco in transition to the Pantanal. Caballero-Gini et al. (2020) reports a total of 15 records at Estancia Playada, which is $\sim 532 \mathrm{~km}$ southeast of Estancias Cerro Corá and Santa Teresa and is next to the Paraguay River. Only one individual was photographed at Estancia San Juan, which lies to the west of the other three and is further away from the Paraguay River and its adjacent humid environments. This suggests that Estancia San Juan lies on the range margin of the species, possibly due to the low availability of water in the region as compared to Estancias Santa Teresa, Cerro Corá and Playada.

\section{Literature cited}

Asociación Paraguaya de Mastozoología and Secretaría del Ambiente. 2017. Libro rojo de los mamíferos del Paraguay: Especies amenazadas de extinción. Editorial CREATIO. Asunción, Paraguay.

Caballero-Gini, A., D. Bueno-Villafañe, R. Laino, and K. Musálem. 2020. Diversity of mammals and birds recorded with cameratraps in the Paraguayan Humid Chaco. Boletín del Museo Nacional de Historia Natural del Paraguay 24:5-14.
Catzeflis, F., J. Patton, A. Percequillo, and M. Weksler. 2016. Dasyprocta azarae. In: IUCN 2016. The IUCN Red List of Threatened Species. www.iucnredlist.org. Downloaded on 22 April 2020.

Chatellenaz, M., G. Villordo, and J. L. Anchetti. 2015. Confirmación de la presencia del agutí bayo, Dasyprocta azarae (Rodentia: Dasyproctidae) en Corrientes, Argentina. Acta Zoológica Lilloana 59:155-158.

de La Sancha, N.U., and M. L. Ortiz. 2017. An annotated checklist of the mammals of Paraguay. Therya 8:241-260.

de Oliveira, T., A. Paviolo, J., Schipper, R. Bianchi, E. Payan, and S. V. Carvajal. 2015. Leopardus wiedii. In: IUCN 2015. The IUCN Red List of Threatened Species. www.iucnredlist.org. Downloaded on 22 April 2020.

Gamarra de Fox, I., And A. Martin (eds.). 1996. Colecciones de flora y fauna del Museo de Historia Natural del Paraguay. Museo Nacional de Historia Natural del Paraguay. Asunción, Paraguay. Gonzáles, A. R., C. Benitez, M. Ferreira, N. Cantero, A. Arias, L. Matosso, and V. Rojas Bonzı. 2019. Mamíferos medianos y grandes de la Reserva Pantanal: Estación Los Tres Gigantes, Alto Paraguay, Paraguay. Paraquaria Natural 7:8-18.

Londoño-Gaviria, M., P. Teta, S. D. Ríos, and B. D. Patterson. 2018. Redescription and phylogenetic position of Ctenomys dorsalis Thomas 1900, an enigmatic tuco tuco (Rodentia, Ctenomyidae) from the Paraguayan Chaco. Mammalia 83:227-236.

Mereles, F., J. L. Cartes, R. P. Clay, P. Cacciali, C. Paradeda, O. RoDAS, AND A. YANosky. 2013. Análisis cualitativo para la definición de las ecorregiones de Paraguay Occidental. Paraquaria Natural 6:12-20. 
Myers, P., A. Taber, and I. Gamarra de Fox. 2002. Mamíferos de Paraguay. Pp. 453-502 in Diversidad y Conservación de los Mamíferos Neotropicales (Ceballos, G., and J. A. Simonetti, eds.). CONABIO-UNAM. México City, Mexico.

Patton, J. L., AND L. H. Emmons (eds.). 2015. Mammals of South America, Volume 2, Rodents. The University of Chicago Press. Chicago, U.S.A.

Redford, K. H., And J. F. Eisenberg. 1992. Mammals of the Neotropics, Volume 2, The Southern Cone: Chile, Argentina, Uruguay, Paraguay. The University of Chicago Press. Chicago, U.S.A.

Ruмво, M. 2010. Análisis biogeográfico de los mamíferos de Paraguay. Boletín del Museo Nacional de Historia Natural del Paraguay 16:18-29.

Wilson, D. E., ANd D. M. Reeder (eds). 2005. Mammal Species of the World, a Taxonomic and Geographic Reference, 3rd edition. Johns Hopkins Press. Baltimore, U.S.A.

Associated editor: Beatriz Bolívar-Cimé

Submitted: May 6, 2020; Reviewed: June 16, 2020.

Accepted: June 17, 2020; Published on line: June 25, 2020. 